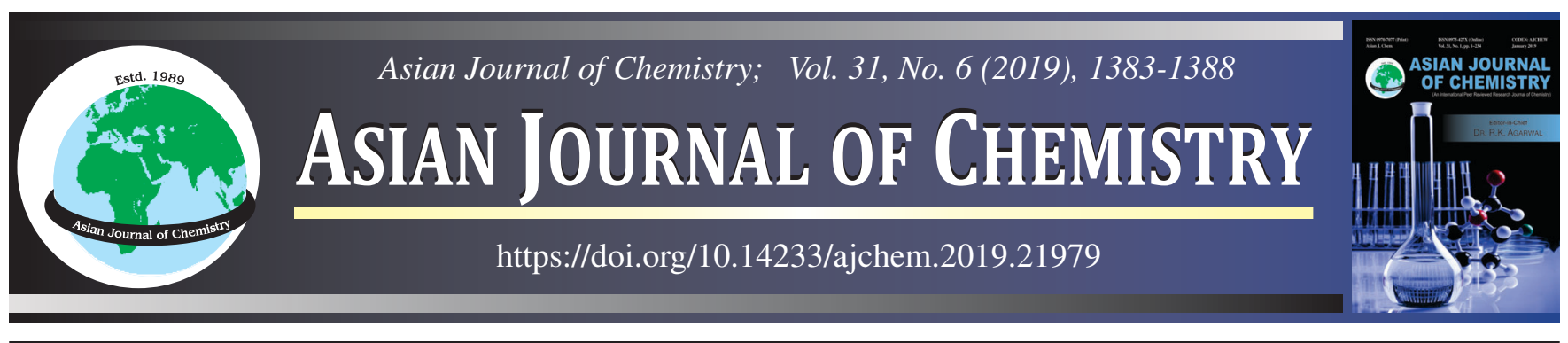

\title{
Mononuclear Binary Complex Formation Equilibria of L-Ornithine with Biologically Essential Metals in TBAB Micellar Media
}

\author{
A.G. Atnafu ${ }^{1}$, R. SRinivasu ${ }^{2}$, P. ShyAmala ${ }^{2}$ and G. NAGESWARA RaO ${ }^{1, *}$
}

${ }^{1}$ Department of Inorganic and Analytical Chemistry, Andhra University, Visakhapatnam-530003, India

${ }^{2}$ Department of Physical and Nuclear Chemistry and Chemical Oceanography, Andhra University, Visakhapatnam-530003, India

*Corresponding author: E-mail: gollapallinr@yahoo.com; shyamalapulipaka06@gmail.com

Received: 6 February 2019;

Accepted: 19 March 2019;

Published online: 29 April 2019;

AJC-19384

Investigation of mononuclear complex of L-ornithine in tetrabutylammonium bromide (TBAB, a cationinc surfactant) micelle media has been made $\mathrm{pH}$ metrically at constant temperature and ionic strength in different percentage of micellar solutions (0.0-2.5\%). Stability constants and best fit model for metal complexes were obtained by MINIQUAD75 computer program on the basis of the analysis of residues and other statistical parameters. Accordingly, $\mathrm{ML}, \mathrm{ML}_{2}, \mathrm{MLH}$ and $\mathrm{ML}_{2} \mathrm{H}$ for both $\mathrm{Co}(\mathrm{II})$ and $\mathrm{Cu}(\mathrm{II})$ and $\mathrm{ML}_{2}$ and $\mathrm{ML}_{2} \mathrm{H}$ for | $\mathrm{Ni}$ (II) mononuclear chemical models were obtained. The stabilization/destabilization equilibria of the binary system for the model species with percentage composition of micelles at constant ionic strength and temperature could be attributed to dielectric constant and other intrinsic interaction properties of tetrabutylammonium bromide micelle with ligands and metal ions. The plot of percentage of species against $\mathrm{pH}$ values has been generated from SIM refined data using origin85 software.

Keywords: Complex equilibria, Metal ions, L-Ornithine, TBAB, MINIQUAD75.

\section{INTRODUCTION}

Complexes of metal ions play an important catalytic role in various enzymatic reactions where the reaction mechanism involves the formation of metal-enzyme species. The action of metal ions in biological systems which contain several complex forming molecules like amino-acids, peptides, proteins, carboxylic acids, etc. is closely related to selective formation of complexes with these ligands. Therefore, determination of stability constants of metal-ligand complexes is very important in biosystem or coordination chemistry [1-6].

When a metal ion is in contact with single/several ligands, there is a chance of formation of a number of species depending on the concentrations of metal ions, concentrations of ligand and other environmental conditions of the biosystem surrounding it $[3,4]$. The activity of a metal ion or a ligand depends on the actual form of the chemical species in which the metal ion exists $[5,6]$. The term chemical species refers to this specific form of an element in a particular oxidation state or molecular structure and chemical speciation study is the analytical study of identifying/measuring the quantity of one or more individual chemical species in a sample [3]. Information regarding the nature and extent of formation of species as a function of $\mathrm{pH}$ can be obtained from speciation study $[7,8]$.

L-Ornithine (L-Orn) is a non-protein 2,5-diaminopentanoic acid whose metal complexes are insoluble in water and soluble in most organic solvents [9]. It is a tridentate ligand [10,11] and known to form several stable metal ion complexes in a variety of solvents differing in the degree of solubility: with $\mathrm{Co}(\mathrm{II}), \mathrm{Ni}(\mathrm{II})$ and $\mathrm{Cu}(\mathrm{II})$ [12-22]; $\mathrm{Cd}(\mathrm{II}), \mathrm{Sn}(\mathrm{IV}), \mathrm{Ce}(\mathrm{IV})$ and $\mathrm{Pd}(\mathrm{II})$ in different solvents [23-27]. L-Ornithine complexes of bio-essential metals play an important role in chemotherapeutic applications [28,29]. For instance Orn-Cu(II) complexes showed excellent antimicrobial activity [30], Orn$\mathrm{Cd}(\mathrm{II})$ and $\mathrm{Orn}-\mathrm{Cu}$ (II) proteasome inhibitors and apoptosis inducers in human cancer cells [31]. L-Ornithine also helps to build muscles, reduces body fats, removes toxic ammonia in urea cycle from liver [32] and is the source of polyamines in maintaining physiological system.

\section{EXPERIMENTAL}

All chemicals used were of analytical reagent grade from which corresponding solutions were prepared in triply distilled

This is an open access journal, and articles are distributed under the terms of the Creative Commons Attribution-NonCommercial-ShareAlike 4.0 (CC BY-NC-SA 4.0) International License which allows readers to freely read, download, copy, distribute, print, search, or link to the full texts of its articles and to use them for any other lawful non-commercial purpose as long as the original source is duly acknowledged. 
water free of dissolved oxygen or carbon dioxide via purging nitrogen gas in to it. Solutions of $\sim 0.05 \mathrm{~mol} \mathrm{dm}^{-3}$, L-ornithine (Sigma-Aldrich, India), $0.4 \mathrm{~mol} \mathrm{dm}^{-3}$ of sodium hydroxide and $0.2 \mathrm{~mol} \mathrm{dm}^{-3}$ hydrochloric acid (both Merck, India) were prepared. Carbonates were removed from $\mathrm{NaOH}$ through regular Gran titration. $\mathrm{NaOH}$ was standardized against potassium hydrogen phthalate and used to standardize $\mathrm{HCl}$ solution before use. $\mathrm{A} \sim 0.1 \mathrm{~mol} \mathrm{dm}^{-3}$ solutions of $\mathrm{Cu}$ (II), $\mathrm{Co}$ (II) and $\mathrm{Ni}$ (II) (all E-Merck, Germany) were prepared from the corresponding chloride salts and standardized by complexometric titration method. The ligand solutions (to increase their solubility) and metal solutions (to repress their hydrolysis) were maintained in $0.05 \mathrm{~mol} \mathrm{dm}^{-3} \mathrm{HCl}$. Tetrabutylammonium bromide (TBAB) (Merck, India) were used as received. 0.5-2.5\% percentage solutions were successively prepared for TBAB. The ionic strength of the titration mixture was maintained to be $0.16 \mathrm{~mol} \mathrm{dm}^{-3}$ sodium chloride (Merck, India) in a total volume of $50 \mathrm{~mL}$.

Methods and equipments: Potentiometric titrations were conducted in micellar media by using Metrohm 877 titrino plus auto-titrator (Switzerland) (readability 0.001) in conjunction with electrode of $0-14 \mathrm{pH}$ reading at the temperature of $298 \mathrm{~K}$ and purified nitrogen atmosphere as described elsewhere [33]. The electrode was calibrated with $0.1 \mathrm{~mol} \mathrm{dm}^{-3}$ potassium hydrogen phthalate $(\mathrm{pH} 4.01)$ and $0.05 \mathrm{~mol} \mathrm{dm}^{-3}$ borax solutions ( $\mathrm{pH}$ 9.18). It was also equilibrated in well stirred solvent with regular checking via initial titration of strong acid with alkali solution. After equilibration of the electrode, the data obtained by the three replicate titration measurements were reproducible and found to differ by not more than 0.02 units.

Data processing for selection of best fit models: In this study, the relative compositions of chemical species (their complexes and free forms) formed by the interactions between metal ions and ligand (L-ornithine) at the given set of experi- mental conditions ( $\mathrm{pH}$, temperature and ionic strength) have been determined using the modified [34] Calvin-Wilson titration technique.

A total volume of $50 \mathrm{~mL}$ titration mixtures containing different percentage of surfactants, ligand and fixed concentration of metal ions in an ionic strength of $0.16 \mathrm{~mol} \mathrm{dm}^{-3} \mathrm{NaCl}$ and $298 \mathrm{~K}$ has been carried out to study the formation of binary complexes. Determination of metal ligand stability constants was performed by the titration of metal ion-ligand mixtures with $0.05 \mathrm{~mL}$ sodium hydroxide $\left(0.4 \mathrm{~mol} \mathrm{dm}^{-3}\right)$ at regular interval. For each experimental data point, the metal to ligand ratios were kept to be 1:1, 1:2 and 1:3 (M:L) to form mononuclear complexes. The titrimetric data generated were automatically saved in the instrument (Metrohm 877 titrino plus auto-titrator). The effect of variations in liquid junction potential, asymmetry potential, dielectric constant, sodium ion error, dissolved carbon dioxide and activity coefficient on the response of the electrode were accounted for by correction factor which was calculated using SCPHD [35] program. The stability constants of the binary complexes were determined by MINIQUAD75 computer program $[35,36]$ using value of correction factor as initial imputes and fixed values of $\mathrm{Kw}$ and protonation constants of the ligand during refinement.

\section{RESULTS AND DISCUSSION}

Modeling of chemical species: The outcomes of the best fit models that represent the different types of chemical species and their stochiometric ratio and stability constant values are given in Table-1. The detection of all plausible species in the form of non-protonated and protonated complexes that best fit with the model for metal-ligand system is also given in Fig. 1. The validity and sufficiency of the chemical models

\begin{tabular}{|c|c|c|c|c|c|c|c|c|c|c|}
\hline \multirow{3}{*}{$\begin{array}{c}\text { TBAB } \\
(\%)\end{array}$} & \multicolumn{9}{|c|}{$\begin{array}{l}\text { TABLE-1 } \\
\text { PARAMETERS OF BEST FIT CHEMICAL MODELS OF Co(II), Ni(II) AND } \\
\text { Cu(II)-L-ORNITHINE COMPLEXES IN TBAB-WATER MIXTURES }\end{array}$} & \multirow{3}{*}{$\mathrm{R}$} \\
\hline & \multicolumn{4}{|c|}{$\log \beta_{\mathrm{MLH}}$} & \multirow{2}{*}{ NP } & \multirow{2}{*}{$\mathrm{U}_{\text {corr }}$} & \multirow{2}{*}{ Skewness } & \multirow{2}{*}{ Kurtosis } & \multirow{2}{*}{$\chi^{2}$} & \\
\hline & ML & MLH & $\mathrm{ML}_{2}$ & $\mathrm{ML}_{2} \mathrm{H}$ & & & & & & \\
\hline \multicolumn{11}{|c|}{$\mathrm{Co}(\mathrm{II})(\mathrm{pH} 2.0-9.5)$} \\
\hline 0.0 & $7.86(17)$ & $10.3(20)$ & $15.91(31)$ & $23.59(37)$ & 104 & 3.04 & -0.33 & 4.63 & 25.08 & 0.0110 \\
\hline 0.5 & $7.68(18)$ & $9.98(23)$ & $15.25(30)$ & $23.02(31)$ & 115 & 8.48 & -0.49 & 2.77 & 12.22 & 0.0155 \\
\hline 1.0 & $7.03(12)$ & $9.34(13)$ & $14.80(25)$ & $22.57(26)$ & 143 & 5.47 & -0.07 & 2.91 & 23.68 & 0.0125 \\
\hline 1.5 & $6.52(9)$ & $9.41(21)$ & $14.17(20)$ & $22.53(16)$ & 81 & 4.29 & 0.10 & 3.43 & 4.28 & 0.0091 \\
\hline 2.0 & $6.27(7)$ & $8.72(10)$ & $12.81(12)$ & $21.68(11)$ & 96 & 3.72 & 0.29 & 3.38 & 12.95 & 0.0136 \\
\hline 2.5 & $5.93(15)$ & $8.33(17)$ & $12.71(22)$ & $21.62(16)$ & 74 & 6.41 & -0.09 & 2.39 & 3.65 & 0.0214 \\
\hline \multicolumn{11}{|c|}{$\mathrm{Cu}(\mathrm{II})(\mathrm{pH} 1.8-7.5)$} \\
\hline 0.0 & $17.65(6)$ & $20.18(14)$ & $30.87(29)$ & $36.18(18)$ & 143 & 6.35 & -0.15 & 3.28 & 43.56 & 0.019659 \\
\hline 0.5 & $16.93(12)$ & $19.79(20)$ & $27.99(55)$ & $34.23(25)$ & 96 & 5.76 & 0.08 & 2.53 & 8.56 & 0.015053 \\
\hline 1.0 & 16.51(9) & $19.80(9)$ & $26.79(75)$ & $33.52(14)$ & 73 & 1.37 & 0.06 & 1.73 & 77.73 & 0.006239 \\
\hline 1.5 & $16.95(9)$ & $18.93(41)$ & $28.35(33)$ & $34.47(13)$ & 69 & 3.23 & -0.05 & 2.66 & 9.08 & 0.016845 \\
\hline 2.0 & $17.48(9)$ & $19.21(45)$ & $28.27(70)$ & $34.90(14)$ & 91 & 1.24 & -0.25 & 2.50 & 29.27 & 0.022362 \\
\hline 2.5 & $16.47(9)$ & 19.93(6) & $26.54(64)$ & $33.16(16)$ & 91 & 1.87 & 0.05 & 1.97 & 95.85 & 0.006528 \\
\hline \multicolumn{11}{|c|}{$\mathrm{Ni}(\mathrm{II})(\mathrm{pH} 2.4-10.5)$} \\
\hline 0.0 & - & - & $14.67(35)$ & $23.43(23)$ & 45 & 22.39 & 0.21 & 5.01 & 19.61 & 0.0539 \\
\hline 0.5 & - & - & $13.91(15)$ & $22.95(10)$ & 109 & 6.46 & -0.72 & 4.34 & 10.44 & 0.0244 \\
\hline 1.0 & - & - & $12.97(18)$ & $22.56(12)$ & 89 & 10.21 & -0.77 & 3.36 & 7.55 & 0.0284 \\
\hline 1.5 & - & - & $12.81(16)$ & $22.46(12)$ & 101 & 9.62 & -0.88 & 4.18 & 16.29 & 0.0285 \\
\hline 2.0 & - & - & $12.42(14)$ & $22.22(11)$ & 104 & 8.29 & -0.88 & 3.76 & 11.79 & 0.0259 \\
\hline 2.5 & - & - & $11.82(15)$ & $21.95(12)$ & 102 & 9.86 & -0.89 & 3.60 & 13.48 & 0.0285 \\
\hline
\end{tabular}

$\mathrm{U}_{\text {corr }}=\mathrm{U} /(\mathrm{NP}-\mathrm{m}) \times 10^{8}$, where $\mathrm{m}=$ number of species; $\mathrm{NP}=$ number of experimental points 

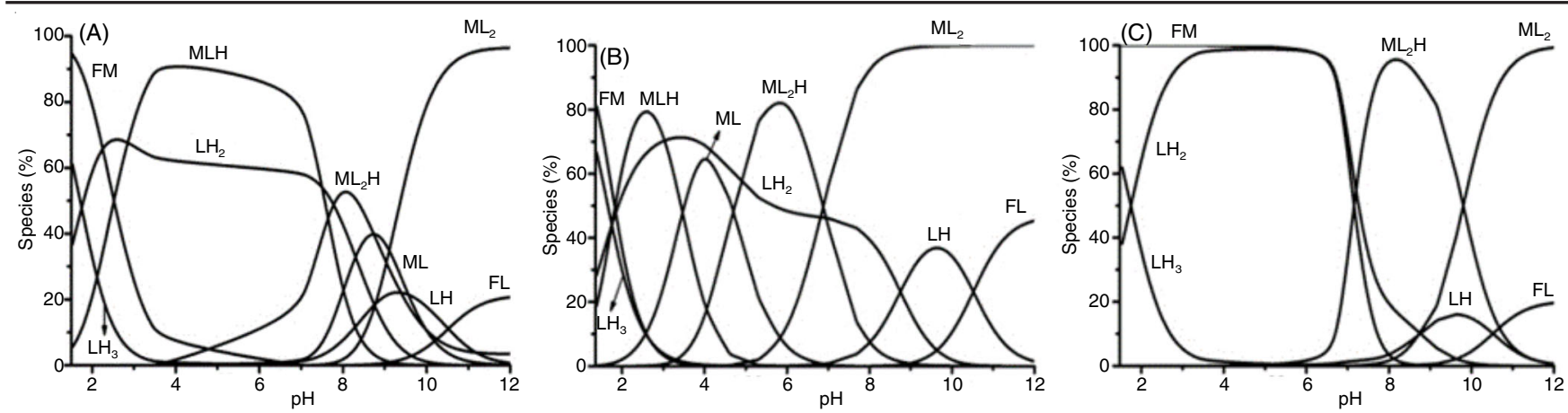

Fig. 1. Concentration distribution diagrams of L-ornithine complexes in $1.5 \%$ v/v TBAB-water mixture. (A) $\mathrm{Co}$ (II) (B) $\mathrm{Cu}$ (II) and (C) Ni(II). The analytical concentrations of metal and ligand are: $\mathrm{M}(\mathrm{II}): \sim 0.1$ and L-ornithine: $0.05 .\left(\mathrm{mol} \mathrm{L}^{-1}\right)$

that represent the metal-ligand system to qualify as best fit model to experimental data have been tested based on sum of squares of residuals in mass balance equations ' $U$ ', the standard deviations in refined overall stability constants, chi-square, skewness, kurtosis and crystallographic R-factor. These statistical parameters satisfy the requirements for the least square method to be applied to the data presented. The small values of standard deviations ensure that the parameters employed are precise. The residuals with skewness values of -0.49 to 0.29 for $\mathrm{Co}$ (II)-Orn, -0.03 to 0.08 for $\mathrm{Cu}$ (II)-Orn and -1.41 to 0.21 for $\mathrm{Ni}$ (II)-Orn systems form part of the guassian (normal) distribution for M(II)-Orn system. The values of kurtosis shows both meso and slight leptokurtic pattern for Co(II)-Orn and leptokurtic pattern (> 3.0) for Ni(II)-Orn systems and platykurtic pattern for $\mathrm{Cu}$ (II)-Orn ( $<3$ except in aqueous) in the model distribution. The very small values of crystallographic $\mathrm{R}$-factor (less than the critical value) further strengthen the adequacy of the model to represent the chemical species.

Chemical speciation and species distribution plots: Chemical speciation is determined through various analytical methods in conjunction with mathematical model in order to get the number, types, compositions and distributions as a function of $\mathrm{pH}$ and to assess stability of the species under specified experimental conditions of constant temperature and ionic strength. In this connection, metal-ornithine complexes were studied by determining the overall stability constants and data were subjected to refinement to arrive at the chemically reasonable speciation model that provide satisfactory best fit to the experimental data.

L-Ornithine is a tridentate ligand having two associable amino protons and one dissociable carboxylate proton. It exists as $\mathrm{LH}_{3}{ }^{2+}, \mathrm{LH}_{2}{ }^{+}, \mathrm{LH}$ and $\mathrm{L}^{-}$in the $\mathrm{pH}$ ranges of 2.0-3.5, 2.0-9.0, 8.0-11.0 and 10.0-12.0, respectively. Based on the ligand information and metal-ornithine interactions, the plausible chemical species predicted and refined are $\mathrm{ML}, \mathrm{ML}_{2}, \mathrm{MLH}, \mathrm{ML}_{2} \mathrm{H}$ for both $\mathrm{Co}(\mathrm{II})$ and $\mathrm{Cu}$ (II) and $\mathrm{ML}_{2}$ and $\mathrm{ML}_{2} \mathrm{H}$ for $\mathrm{Ni}$ (II) in micelles-water mixture between 2.0-9.5, 1.8-7.5 and 2.0-10.5 $\mathrm{pH}$ ranges, respectively. The electron pair donor $\mathrm{N}$-atom on $\alpha$-amino and terminal amine functional group of L-ornithine has strong affinity towards hydrogen ions in the physiological $\mathrm{pH}$ ranges. As a result of the high competition between the metal ion and hydrogen ion for electron pair donar $\mathrm{N}$-site, protonated species were likely formed as well. The most likely equilibria for the binary species formation are given as follows for which charges of species are omitted for simplicity:

$$
\begin{aligned}
& \mathrm{M}(\mathrm{II})+\mathrm{LH}_{3} \rightleftharpoons \mathrm{MLH}+2 \mathrm{H}^{+} \\
& \mathrm{M}(\mathrm{II})+\mathrm{LH}_{2} \rightleftharpoons \mathrm{MLH}+\mathrm{H}^{+} \\
& \mathrm{M}(\mathrm{II})+2 \mathrm{LH}_{3} \rightleftharpoons \mathrm{ML}_{2} \mathrm{H}+5 \mathrm{H}^{+} \\
& \mathrm{M}(\mathrm{II})+2 \mathrm{LH}_{2} \rightleftharpoons \mathrm{ML}_{2} \mathrm{H}+3 \mathrm{H}^{+} \\
& \mathrm{MLH}+\mathrm{LH}_{2} \rightleftharpoons \mathrm{ML}_{2} \mathrm{H}+2 \mathrm{H}^{+} \\
& \mathrm{M}+\mathrm{LH}_{3} \rightleftharpoons \mathrm{ML}+3 \mathrm{H}^{+} \\
& \mathrm{M}+\mathrm{LH}_{2} \rightleftharpoons \mathrm{ML}+2 \mathrm{H}^{+} \\
& \mathrm{M}+\mathrm{LH} \rightleftharpoons \mathrm{ML}+\mathrm{H}^{+} \\
& \mathrm{MLH} \rightleftharpoons \mathrm{ML}+\mathrm{H}^{+} \\
& \mathrm{ML}_{2} \mathrm{H} \rightleftharpoons \mathrm{ML}_{2}+\mathrm{H}^{+} \\
& \mathrm{MLH}+\mathrm{LH} \rightleftharpoons \mathrm{ML}_{2}+2 \mathrm{H}^{+} \\
& \mathrm{ML}+\mathrm{LH} \rightleftharpoons \mathrm{ML}_{2}+\mathrm{H}^{+}
\end{aligned}
$$

The relative abundance, types and nature of chemical species are obtained from SIM refined data in the form of distribution diagrams drawn by origin 85 . The interaction of the metal ions of interest with L-ornithine ligand progressively depleted the essential metal ions resulting in the formation of stable M(II)-Orn binary complex species. The concentration distribution diagrams of $\mathrm{M}$ (II)-Orn binary complexes for $\mathrm{Co}$ (II), $\mathrm{Cu}$ (II) and $\mathrm{Ni}$ (II) in Micellar-water mixtures are given in Fig. 1.

$\mathrm{ML}, \mathrm{MLH}, \mathrm{ML}_{2}$ and $\mathrm{ML}_{2} \mathrm{H}$ plausible chemical models have been found to exist for both $\mathrm{Co}$ (II)-Orn and $\mathrm{Cu}$ (II)-Orn systems in the $\mathrm{pH}$ ranges of 1.5-9.5. The $\mathrm{ML}_{2}$ and $\mathrm{ML}_{2} \mathrm{H}$ models were converged and refined for $\mathrm{Ni}(\mathrm{II})$-Orn system in the $\mathrm{pH}$ ranges of 2.4-11.0.

At lower $\mathrm{pH}, \mathrm{MLH}$ and $\mathrm{ML}_{2} \mathrm{H}$ chemical models are formed by the interactions of $\mathrm{LH}_{3}$ and $\mathrm{LH}_{2}$ with the free metal ions [Equilibria (1-4)]. $\mathrm{ML}_{2} \mathrm{H}$ can also be formed by the reaction of MLH and $\mathrm{LH}_{2}$ [Equilibria (5)]. With increasing $\mathrm{pH}$, deprotonation of $\mathrm{MLH}$ and $\mathrm{ML}_{2} \mathrm{H}$ species gives their corresponding ML and $\mathrm{ML}_{2}$ species [Equilibria (9) and (10)], respectively. This co-existence of MLH/ML and $\mathrm{ML}_{2} \mathrm{H} / \mathrm{ML}_{2}$ with deprotonation/protonation dynamic equilibrium might be ensured by the increase in concentration of $\mathrm{ML}$ and $\mathrm{ML}_{2}$ progressively with decreasing concentration of $\mathrm{MLH}$ and $\mathrm{ML}_{2} \mathrm{H}$ in all the M(II)-Orn system.

ML species could be formed by the interactions of the free metal with $\mathrm{LH}_{3}, \mathrm{LH}_{2}$ and $\mathrm{LH}$ [Equilibria (6-8)]. Similarly $\mathrm{ML}_{2}$ species has also been formed by the reactions of $\mathrm{LH}$ with MLH and LH at higher $\mathrm{pH}$ [Equilibria (11) and (12)]. The decrease in concentration of the free metal to lower values 
and to zero values at extreme higher $\mathrm{pH}$ indicates its strong participation in the complex formation equilibria. With the complete depletion of the metal ions in the post active $\mathrm{pH}$ regions of the complex formation equilibria, the concentration of the free ligand drastically increases.

Interpretation of systematic errors: Changing experimental conditions and the concentrations of ingredients of the titration mixture alter the position of acid-base equilibria between the metal ion and the ligand. It in turn, significantly affects the magnitudes of stability constants. Deliberate introduction of pessimistic errors in concentrations of alkali, mineral acid, ligand and metal ions, most commonly known as influential parameters in the study of M(II)-Orn system in $1.5 \% \mathrm{v} / \mathrm{v}$ micelle -water mixture has been made to ensure the appropriateness of the experimental conditions and the choice of the best fit models (Table-2).

TABLE-2

EFFECT OF ERRORS IN INFLUENTIAL PARAMETERS ON THE CO-ORNITHINE COMPLEX STABILITY CONSTANTS IN $1.5 \%(\mathrm{v} / \mathrm{v})$ TBAB-WATER MIXTURE

\begin{tabular}{|c|c|c|c|c|c|}
\hline \multirow{2}{*}{ Ingredient } & \multirow{2}{*}{$\begin{array}{c}\text { Error } \\
(\%)\end{array}$} & \multicolumn{4}{|c|}{$\log \beta_{\mathrm{MLH}}(\mathrm{SD})$} \\
\hline & & ML & MLH & $\mathrm{ML}_{2}$ & $\mathrm{ML}_{2} \mathrm{H}$ \\
\hline \multirow{5}{*}{ Acid } & 0 & $6.52(09)$ & $9.41(21)$ & $14.17(20)$ & $22.52(16)$ \\
\hline & -5 & Rejected & Rejected & Rejected & Rejected \\
\hline & -2 & $6.06(09)$ & Rejected & $15.57(20)$ & Rejected \\
\hline & +2 & 7.24(19) & $9.71(24)$ & $12.17(32)$ & $20.18(26)$ \\
\hline & +5 & $5.21(20)$ & $10.32(21)$ & $11.17(14)$ & $18.45(25)$ \\
\hline \multirow{4}{*}{ Alkali } & -5 & $8.96(20)$ & 13.71(35) & Rejected & $22.69(23)$ \\
\hline & -2 & $7.92(30)$ & $11.32(41)$ & $16.02(47)$ & $21.18(31)$ \\
\hline & +2 & $5.36(41)$ & Rejected & $12.17(20)$ & $23.43(36)$ \\
\hline & +5 & Rejected & Rejected & Rejected & Rejected \\
\hline \multirow{4}{*}{ Ligand } & -5 & $6.32(10)$ & $10.12(02)$ & $14.05(36)$ & $22.70(38)$ \\
\hline & -2 & $6.45(08)$ & $10.00(12)$ & $14.13(38)$ & $21.87(23)$ \\
\hline & +2 & $6.42(10)$ & $9.61(18)$ & $14.20(36)$ & $22.07(32)$ \\
\hline & +5 & $6.48(13)$ & $9.37(25)$ & $13.83(34)$ & $21.26(37)$ \\
\hline \multirow{4}{*}{ Metal } & -5 & $6.51(12)$ & $9.52(21)$ & $14.47(40)$ & $22.15(16)$ \\
\hline & -2 & $6.43(05)$ & $9.36(08)$ & $14.27(38)$ & $21.68(25)$ \\
\hline & +2 & $6.30(10)$ & $9.25(11)$ & $14.05(32)$ & $21.83(20)$ \\
\hline & +5 & $6.31(07)$ & $9.23(21)$ & $14.23(31)$ & $21.89(35)$ \\
\hline
\end{tabular}

The destabilization/stabilization complex equilibria have been assessed from the magnitude of the overall stability constants their corresponding standard deviation and acceptance/ rejection of certain species refined by MINIQUAD75. The values of the stability constants due to incorporation of the errors resulted from change in concentration of ingredients were found to be more significantly affected by alkali and acid but less affected by concentration of ligand and metal ions (Table-3). This is noted from the high standard deviation in the $\log \beta$ values and rejection of more species in the alkali and acids compared to the metal and ligands. The resulted high standard deviation in $\log \beta$ values and species rejection with introduction of errors signifies the appropriateness of the model and relative precision of the analytical concentrations.

Effects of surfactants: Dielectric constant is one of the most and prominent solvent properties that could be altered by surfactants in the given titration mixtures. The anisotropic water distribution within micellar structure causes non-uniform micropolarity, microviscosity and degree of hydration within the micellar media $[37,38]$. The degree of stability of complexes could be measured in terms of the magnitude of the overall stability constant of each species formed in metal ligand dynamic equilibria. The linear and non-linear variations in the magnitude of the stability constants of metal-ligand complexes are due to electrostatic and non-electrostatic opposing factors, respectively. In the present study results of the stability constants were found to be linearly decreasing as the percentage of surfactants increases progressively. The destabilization of the metal ligand complexes could be attributed mainly to the low dielectric constant of the surfactant mediated solvent compared to aqueous medium. Moreover, the destabilization effect of the low dielectric constant is synergized by the cationic surfactant, TBAB, which causes the $\log \beta$ values to decrease linearly as shown in Fig. 2. On the other hand, the proton accepting ability of the ligand increases in acidic environment (in TBAB). Hence, the metal ion, the protons and TBAB, as a cationic surfactant, compete for the ligand decreasing the full availability of the electron pairs of the ligand making difficult to easily donate to vacant shell of the metal ion. As a result of these competing processes, the stability of the complex and values of the stability constant seems to decrease in TBABwater mixture. This concept is in good agreement with the linearity of plots of $\log \beta$ values $v s$. \% TBAB (low dielectric constant effect of surfactant modified medium).

Structure: It is noted in the literature that octahedral structure has been proposed for $\mathrm{Co}$ (II) and $\mathrm{Ni}$ (II) complexes by different authors. Unlike $\mathrm{Co}$ (II) and $\mathrm{Ni}(\mathrm{II}), \mathrm{Cu}$ (II) complexes has been suggested to have square planar or distorted octahedral structure. The distorted structure for $\mathrm{Cu}$ (II) complexes is accounted for the Jahn-Teller distortion effect $[15,16]$. It is also evident that amino nitrogen electron donor sites have high

\begin{tabular}{|c|c|c|c|c|c|c|c|c|}
\hline \multirow{3}{*}{ Metal ion } & \multicolumn{7}{|c|}{$\begin{array}{l}\text { TABLE-3 } \\
\text { COMPARISON WITH PREVIOUSLY REPORTED LITERATURE VALUES OF Co(II), } \\
\text { Ni(II) AND Cu(II)-L-ORNITHINE COMPLEXES IN TBAB-WATER MIXTURES }\end{array}$} & \multirow{3}{*}{ Ref. } \\
\hline & \multirow{2}{*}{$\begin{array}{l}\text { Medium } \\
\left(\mathrm{mol} \mathrm{L}^{-1}\right)\end{array}$} & \multicolumn{4}{|c|}{$\log \beta_{\mathrm{MLH}}$} & \multirow{2}{*}{ Temp. (K) } & \multirow{2}{*}{$\begin{array}{l}\text { Instrumental } \\
\text { method used }\end{array}$} & \\
\hline & & ML & $\mathrm{ML}_{2}$ & MLH & $\mathrm{ML}_{2} \mathrm{H}$ & & & \\
\hline \multirow{3}{*}{$\mathrm{Co}(\mathrm{II})$} & 1.00 & 5.60 & - & 3.54 & 6.84 & 298 & Potentiometry & [10] \\
\hline & 0.10 & 5.01 & 8.49 & 14.16 & 27.77 & 298 & Potentiometry & [12] \\
\hline & 0.16 & - & 12.71 & - & 21.62 & 298 & Potentiometry & Current work \\
\hline \multirow{2}{*}{$\mathrm{Ni}(\mathrm{II})$} & 1.00 & 7.04 & - & 4.72 & 9.06 & 298 & Potentiometry & {$[10]$} \\
\hline & 0.16 & - & 11.82 & - & 21.95 & 298 & Potentiometry & Current work \\
\hline \multirow{4}{*}{$\mathrm{Cu}(\mathrm{II})$} & 1.00 & 11.30 & - & 7.87 & 14.05 & 298 & Potentiometry & {$[10]$} \\
\hline & 0.10 & - & - & 17.81 & - & 298 & Potentiometry & [12] \\
\hline & 1.00 & - & 15.53 & - & 34.44 & 298 & Potentiometry & - \\
\hline & 0.16 & 16.47 & 19.93 & 26.54 & 33.16 & 298 & Potentiometry & Current work \\
\hline
\end{tabular}



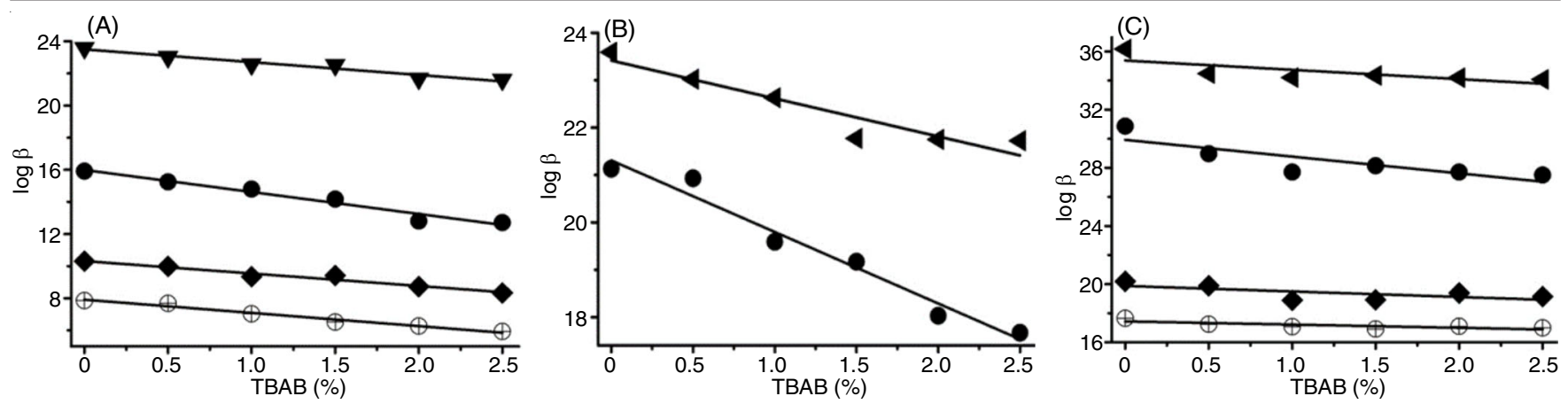

Fig. 2. Variation of stability constants of L-ornithine complexes of (A) $\mathrm{Co}(\mathrm{II})$, (B) $\mathrm{Ni}(\mathrm{II}),(\mathrm{C}) \mathrm{Cu}(\mathrm{II})$ with percentage of surfactants in $\mathrm{TBAB}$ water mixtures: $(\otimes) \log \beta_{110},(\boldsymbol{\square}) \log \beta_{111},(\bullet) \log \beta_{120}$ and ( $\left.\mathbf{\Delta}\right) \log \beta_{121}$

tendency to associate with potential electron pair acceptors (hydrogen ion) in the $\mathrm{pH}$ range of physiological spots. The metal and hydrogen ions are, therefore, in competition for these donor sites. As a result, several protonated and non-protonated complex species co-exist in the acid base equilibria of metal ligand system.

L-Ornithine has two associable amino and one dissociable (exchangeable) carboxylate protons which makes it to act as tridentate chelating agent. At higher $\mathrm{pH}$ region, both the $\alpha$-amino and terminal nitrogen atoms and oxygen atom of the carboxylate functional group have participated in coordinating preferentially with the metal ion resulting the formation of unprotonated complexes. While at lower $\mathrm{pH}$, only the terminal $\mathrm{N}$ - and carboxylate $\mathrm{O}$-atoms preferentially coordinated with the metal ion leaving lone pair electrons in $\alpha$-amino $\mathrm{N}$-atom donated to $\mathrm{H}$-ion. This situation ensured the formation of MLH, $\mathrm{ML}_{2} \mathrm{H}$ complexes at lower $\mathrm{pH}$ and $\mathrm{ML}, \mathrm{ML}_{2}$ complexes at higher $\mathrm{pH}$. Thus, on the basis of integrated chemical knowledge (educational speculation) and literature reported data, the most likely structure of these detected complexes resulted from lone pair-lone pair, lone pair-bond pair and bond pair-bond pair electronic repulsions and Jahn-Teller distortion effect are given in Fig. 3.

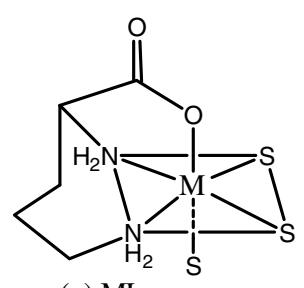

(a) ML

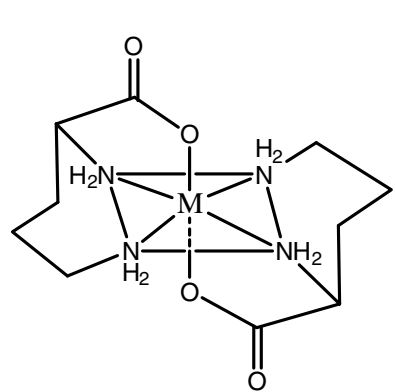

(c) $\mathrm{ML}_{2}$

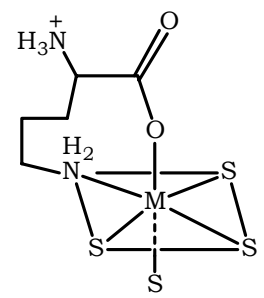

(b) MLH

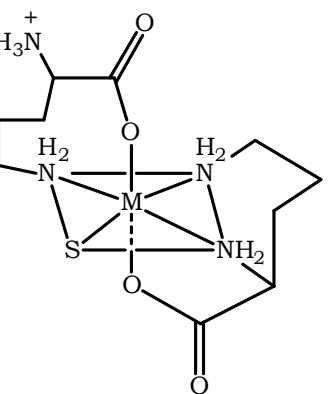

(d) $\mathrm{ML}_{2} \mathrm{H}$
Fig. 3. Most likely structures of M(II)-Orn complexes where $\mathrm{M}$ is ether $\mathrm{Co}(\mathrm{II}), \mathrm{Ni}(\mathrm{II})$ or $\mathrm{Cu}$ (II) and $\mathrm{S}$ is either solvent or water molecule

\section{Conclusion}

In this study, L-ornithine forms protonated species (MLH and $\mathrm{ML}_{2} \mathrm{H}$ ) at low $\mathrm{pH}$ and non-protonated species (ML and $\mathrm{ML}_{2}$ ) at higher $\mathrm{pH}$. The species detected were validated by statistical data

Protonated species were found to deprotonated to give non-protonated species with increasing $\mathrm{pH}$ of titration mixture.

Systematic errors in the influential parameters shows that the errors in the concentrations of alkali and mineral acid were found to affect the overall stability constants of the complex more significantly than that of ligand and metal.

$\log \beta$ values of stability constant were found to decrease linearly with increasing percentage of tetrabutylammonium bromide suggesting the dominance of electrostatic interactions over the non-electrostatic interactions.

\section{ACKNOWLEDGEMENTS}

One of the authors (A.G) thanks Ministry of Education of the Federal Democratic Republic of Ethiopia, University of Gondar, Ethiopia and School of Chemistry, Andhra University, Visakhapatnam, India for sponsorship and material supports.

\section{CONFLICT OF INTEREST}

The authors declare that there is no conflict of interests regarding the publication of this article.

\section{REFERENCES}

1. M.P. Latha, V.M. Rao, T.S. Rao and G.N. Rao, Proc. Nat. Acad. Sci. India, 77A, 109 (2007).

2. D.M. Di Toro, H.E. Allen, H.L. Bergman, J.S. Meyer, P.R. Paquin and R.C. Santore, Environ. Toxicol. Chem., 20, 2383 (2001); https://doi.org/10.1002/etc.5620201034.

3. D.M. Templeton, F. Ariese, R. Cornelis, L.-G. Danielsson, H. Muntau, H.P. van Leeuwen and R. Lobinski, Pure Appl. Chem., 72, 1453 (2000); https://doi.org/10.1351/pac200072081453.

4. A. Gonzalvez, S. Armenta, M.L. Cervera and M. de la Guardia, $\operatorname{Tr} A C$ Trends Analyt. Chem., 29, 260 (2010); https://doi.org/10.1016/j.trac.2009.12.006.

5. A. Gonzalvez, M.L. Cervera, S. Armenta and M. de la Guardia, Anal. Chim. Acta, 636, 129 (2009); https://doi.org/10.1016/j.aca.2009.01.065.

6. A. Ramesh Kumar and P. Riyazuddin, Int. J. Environ. Anal. Chem., 87, 469 (2007); https://doi.org/10.1080/03067310601170415.

7. M. Ghaedi, M. Reza Fathi, A. Shokrollahi and F. Shajarat, Anal. Lett., 39, 1171 (2006); https://doi.org/10.1080/00032710600622167. 
8. A.G. Assefa, R. Srinivasu, P. Shyamala and G.N. Rao, Am. J. Anal. Chem., 9, 397 (2018); https://doi.org/10.4236/ajac.2018.99031.

9. J.S. Sukumar, G.N. Rao, K.V. Ramana and M.S.P. Rao, Indian J. Chem., 35A, 121 (1996).

10. H.H. Belay, B.B.V. Sailaja and G.N. Rao, Der Pharma Chemica, 7, 232 (2015).

11. P.R. Chetana, R. Rao, S. Saha, R.S. Policegoudra, P. Vijayan and M.S. Aradhya, Polyhedron, 48, 43 (2012); https://doi.org/10.1016/j.poly.2012.08.081.

12. M.R. Shehata, M.M. Shoukry, M.A. Mabrouk and R. Van Eldik, J. Coord. Chem., 69, 522 (2016); https://doi.org/10.1080/00958972.2015.1132312.

13. B. Das, K. Ghosh and J.B. Baruah, Synth. React. Inorg. Met.-Org. Chem., 44, 251 (2014); https://doi.org/10.1080/15533174.2013.770754.

14. K.V. Santhee Devi, B.R. Raju and G.N. Rao, Chem. Spec. Bioavail., 22, 191 (2010); https://doi.org/10.3184/095422910X12829312795432.

15. N.V. Kumar and G.N. Rao, Acta Chim. Slov., 58, 342 (2011).

16. P.S. Rao, B. Srikanth, V.S. Rao, C.K. Sastry and G.N. Rao, E-J. Chem., 6, 561 (2009); https://doi.org/10.1155/2009/705976.

17. R. Vegi, L. Muddapu, R. Tirukkuvalluri and R. Gollapalli, J. Serb. Chem. Soc., 73, 1169 (2008); https://doi.org/10.2298/JSC0812169V.

18. P. Bhushanavathi and G.N. Rao, Chem. Spec. Bioavail., 25, 258 (2013); https://doi.org/10.3184/095422913X13838472787746.

19. S. Raju, K.B. Kumar Naik, B.A. Kumar and G.N. Rao, Chem. Spec. Bioavail., 24, 46 (2012); https://doi.org/10.3184/095422912X13257797981584.

20. R.S. Rani and G.N. Rao, Chem. Spec. Bioavail., 25, 187 (2013); https://doi.org/10.3184/095422913X13785546776006.

21. R.R. Bendi, V.S.D. Karri and N.R. Gollapalli, Chem. Spec. Bioavail., 24, 89 (2012); https://doi.org/10.3184/095422912X13324388533472.

22. V.G. Kumari, M. Ramanaiah and B.B.V. Sailaja, Chem. Spec. Bioavail., 27, 121 (2015); https://doi.org/10.1080/09542299.2015.1087159.
23. C. Conato, A. Contino, G. Maccarrone, A. Magrì, M. Remelli and G. Tabbì, Thermochim. Acta, 362, 13 (2000); https://doi.org/10.1016/S0040-6031(00)00633-X.

24. S.A. Lahsasni, R.A. Ammar, M.F. Amin and E.M. Shoukry, Int. J. Electrochem. Sci., 7, 7699 (2012).

25. F. Khan and A. Khanam, Ecl. Quím., São Paulo, 33, 29 (2008); https://doi.org/10.1590/S0100-46702008000200004.

26. Z. Zhang, C. Bi, Y. Fan, N. Zhang, R. Deshmukh, X. Yan, X. Lv, P. Zhang, X. Zhang and Q.P. Dou, J. Biol. Inorg. Chem., 20, 109 (2015); https://doi.org/10.1007/s00775-014-1219-1.

27. M.M. Shoukry and M.M.H. Mohamed, J. Coord. Chem., 43, 225 (1998); https://doi.org/10.1080/00958979808022670.

28. S. Muthusamy and R. Natarajan, J. Chem. Biol. Ther, 1, 2 (2016).

29. D.Y. Pharr, Anal. Lett., 44, 2287 (2011); https://doi.org/10.1080/00032719.2010.551689.

30. E.W. Wilson, M.H. Kasperian and R.B. Martin, J. Am. Chem. Soc., 92, $5365(1970)$ https://doi.org/10.1021/ja00721a013.

31. S.A. Lahsasni, R.A. Ammar, M.F. Amin and M.E. Shoukry, Int. J. Electrochem. Sci., 7, 7699 (2012)

32. S.J. Malode, J.C. Abbar and S.T. Nandibewoor, Synth. React. Inorg. Met.-Org. Nano-Met. Chem., 40, 246 (2010); https://doi.org/10.1080/15533171003766519.

33. M.M. Shoukry, W.M. Hosny and M.M. Khalil, Transition Met. Chem., 20, 252 (1995); https://doi.org/10.1007/BF00143487.

34. H.M. Irving and H.S. Rossotti, J. Chem. Soc., 3397 (1954);

35. G.N. Rao, Ph.D. Thesis, Complex Equilibria of Some Biologically Important Metal Ions in Aquo-organic Media, Andhra University, Visakhapatnam, India (1989).

36. P. Gans, A. Sabatini and A. Vacca, Inorg. Chim. Acta, 18, 237 (1976); https://doi.org/10.1016/S0020-1693(00)95610-X

37. Z. Yuanqin, Talanta, 56, 705 (2002); https://doi.org/10.1016/S0039-9140(01)00618-X.

38. A.L. Underwood, Anal. Chim. Acta, 140, 89 (1982); https://doi.org/10.1016/S0003-2670(01)95455-8. 